\title{
Evaluation of Recombinant Human Tumor Necrosis Factor by Scheduled Intratumoral Administration in Mice Bearing Transplantable Tumors
}

\author{
KeiJi Tamura, ${ }^{*}$ Hisashi Aso, Takehiko Nakamura, ${ }^{*}$ \\ Hiromichi Hemmi $\dagger$ and Nakao Ishida $\ddagger$ \\ Department of Bacteriology, Tohoku University School of \\ Medicine, Sendai 980
}

Tamura, K., Aso, H., Nakamura, T., Hemmi, H. and Ishida, N. Evaluation of Recombinant Human Tumor Necrosis Factor by Scheduled Intratumoral Administration in Mice Bearing Transplantable Tumors. Tohoku J. Exp. Med., 1989, 157 (2), 107-118 — The antitumor effect of recombinant human tumor necrosis factor (rTNF) was examined against Meth A fibrosarcoma in BALB/c mice and Sarcoma-180 in ddY mice. Significant hemorrhagic necrosis in tumor tissues occurred within $24 \mathrm{hr}$ when optimal rTNF (1,000 to 5,000 units per mouse) was injected intratumorally on day 5 after intradermal inoculation of $5 \times 10^{5}$ tumor cells. Complete tumor regression resulted when two repeated courses of administration a week, each for 3 consecutive days, were given. For this marked effect to occur, however, initial tumor weight should not be greater than $1 \mathrm{~g}$. When the initial tumor was greater than $1 \mathrm{~g}$ the surgical removal of tumor tissues was conducted and followed by rTNF administration. This caused hemorrhagic necrosis and the regression was the case with smaller tumors. When the cured mice were rechallenged with same tumors, more than $60 \%$ of mice rejected the tumors in a specific manner. In spite of such demonstration of specific immunity, well-known immunological effector mechanisms such as augmentation of natural killer cell activity, activation of antibody dependent cellular cytotoxicity or induction of interferon activity by rTNF were not detected in normal and tumorbearing mice, suggesting that the activation of immunoregulatory cells by TNF itself may not involve at least in an early stage of TNF treatment. These results suggest that rTNF is a potent therapeutic agent for a certain solid tumor when the protocol of administration is optimized.—recombinant human TNF $(\mathrm{rTNF})$; mouse solid tumors; complete regression

Received October 15, 1988; rerevision accepted for publication January 18, 1989. This study was supported in part by a grant from the Sendai Institute of Microbiology. Abbreviations used are rTNF, recombinant human tumor necrosis factor; NK, natural killer ; ADCC, antibody-depenent cellular cytotoxicity ; IFN, interferon ; i.v., intravenously, i.t., intratumorally ; i.p., intraperitoneally ; s.c., subcutaneously.

*Present address : Saikin Kagaku Institute Co., Ltd., 5-12 Hayamacho, Sendai 981. $\nmid$ Present address: Sagami Chemical Research Center, Sagamihara 229, Kanagawa. $\ddagger$ Present address : Tohoku University, Katahira, Sendai 980 . 
Tumor necrosis factor (TNF), a cytokine released by activated monocytes and/or macrophages, shows in vitro cytotoxicity to a wide variety of human and animal malignant cells including cell lines such as mouse L cells, P388, HL-60, ML-1, HeLa, and Raji and fresh cells of cancer patients in primary culture (Carswell et al. 1975; Ha et al. 1985; Haranaka et al. 1985; Kull et al. 1985 ; Watanabe et al. 1985; Yoshie et al. 1986) and causes hemorrhagic necrosis followed by tumor regression in transplanted tumors in mice (Matthews 1981, 1983 ; Fisch and Gifford 1983; Kelker et al. 1985). Human TNF has been purified and the cDNA was cloned and expressed in Escherichia coli in several laboratories (Pennica et al. 1984 ; Marmenout et al. 1985 ; Shirai et al. 1985). Recombinant (r) TNF possesses similar activities to natural TNF in vitro and in vivo (Pennica et al. 1984 ; Shirai et al. 1985). However, the regiments to accomplish the complete tumor regression in rTNF-treated animals were poorly detailed. In present study, to evaluate the antitumor effect of rTNF in mice, we first investigated the occurrence of hemorrhagic necrosis in each animal and of final tumor regressions by giving intratumor injections of rTNF in a sequential manner. Further, an adequate initial tumor size was determined to obtain the complete regression of tumors. In addition, establishment of specific immunity after complete regression was examined by evaluating resistance to the same tumor rechallenge.

\section{Materials and Methods}

Mice and tumors

$\mathrm{BALB} / \mathrm{c}$ and ddY male mice, 6 weeks old, were obtained from the Shizuoka Laboratory Animal Center, Hamamatsu, Shizuoka. Ascitic form of the Meth A fibrosarcoma and RL 今 1 lymphoma was maintained in syngeneic BALB/c mice. The Sarcoma-180, ascitic form, and Ehrlich ascitic tumor were maintained in ddY mice. These tumor cells were intradermally (i.d.) inoculated into the abdomen of the mice, 7 to 8 weeks old.

$r T N F$

rTNF $\left(2.1 \times 10^{6}\right.$ units $/ \mathrm{mg}$ protein $)$ was kindly donated by Asahi Chemical Industry Co., Ltd., Tokyo. The stock solution of rTNF was $10^{5}$ units $/ \mathrm{ml}$ of $5 \mathrm{mM}$ phosphate buffered saline, $\mathrm{pH} 7.4$, containing $0.1 \%$ gelatin. Further dilutions were made by the same buffer. $\mathrm{TNF}$ activity was preserved for more than 6 months when stored at below $-20^{\circ} \mathrm{C}$.

\section{In vitro TNF assay}

To standardize rTNF activity, the following two assay systems were employed.

(a) Cytotoxic assay: Cytotoxicity to mouse L-M cells was determined by the dyestaining method as described (Hemmi et al. 1987). The cytotoxic activity of rTNF measured in our laboratory was reproducible in the Asahi Chemical Industry Co.

(b) Enzyme-linked immunosorbent assay (ELISA): TNF titer was also determined by the ELISA using a solid-phase sandwich procedure (Yamazaki et al. 1986). The minimum amount detected was $500 \mathrm{pg}$ of which is equivalent to 1 unit in the cytotoxic assay. 
In vivo TNF assay

rTNF was injected intratumorally (i.t.) to tumor-bearing mice. The tumor weight was calculated by a following formula: tumor weight $(\mathrm{gram})=10^{0.038(a+b)-1}$, where $a$ is the larger and $b$ is the shorter diameter $(\mathrm{mm})$. The hemorrhagic necrosis was determined at 24 $\mathrm{hr}$ after TNF injection and the extent of necrosis was evaluated when more than $50 \%$ of tumor mass became necrotic. The complete regression was defined when the tumor was not regrown for more than 60 days. Without treatment, tumor-bearing mice died on day 25 to 35 .

\section{NK activity}

$\mathrm{NK}$ activity of splenocytes isolated from $\mathrm{rTNF}$-treated BALB/c mice were measured against mouse YAC-1 cells (Aso et al. 1985). Human IFN- $\alpha \mathrm{A} / \mathrm{D}\left(b g l ; 1.5 \times 10^{8} \mathrm{units} / \mathrm{mg}\right.$ protein, Nippon Roche Research Center, Kamakura) was used as a positive control.

\section{$A D C C$}

ADCC of peritoneal exuded cells against chicken red blood cells was determined as described (Nakamura et al. 1986). Human IFN- $\alpha$ A/D was used as a positive control.

INF assay

IFN titer in the serum of BALB/c mice was determined by the cytopathic method using mouse L-929 cells and vesicular stomatitis virus (Aso et al. 1985).

\section{RESULtS}

\section{Treatment of tumor-bearing mice}

The antitumor activity of rTNF against Meth A fibrosarcoma in BALB/c mice was studied. Treatment was started at day 5 and continued another 2 days

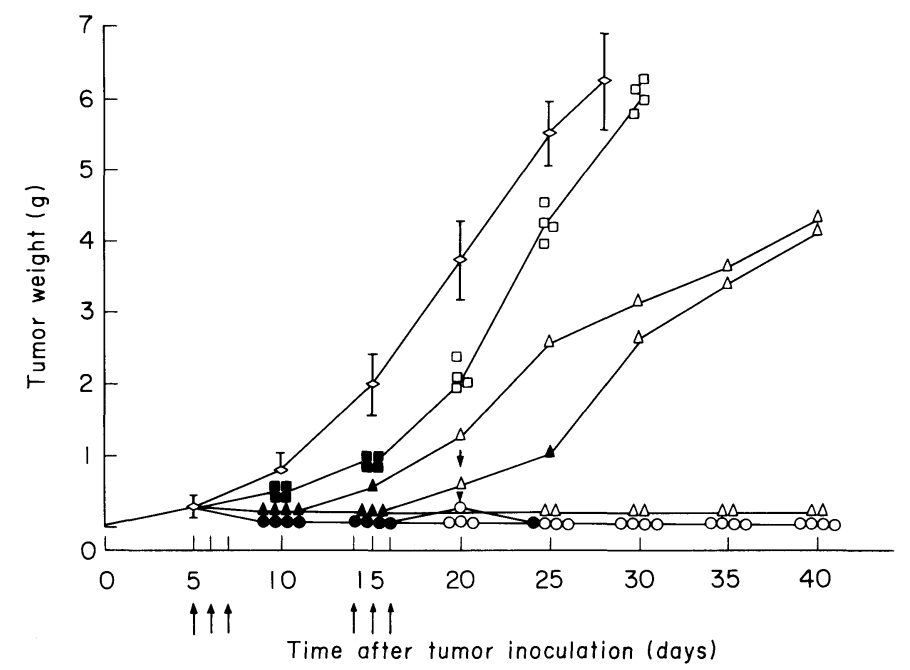

Fig. 1. Treatment with rTNF of BALB/c mice transplanted with Meth A fibrosarcoma. Meth A ( $10^{6}$ cells) was inoculated i.d. and $50 \mu$ l of various concentrations of rTNF was injected i.t. at days indicated by allows. The doses of rTNF used were none $(\diamond), 10^{3}$ units $(\square, \boldsymbol{\square}), 3 \times 10^{3}$ units $(\triangle, \Delta)$, and $5 \times 10^{3}$ units $(\circ, \bullet)$ per day. Closed symbols show hemorrhagic necrosis occurred. 

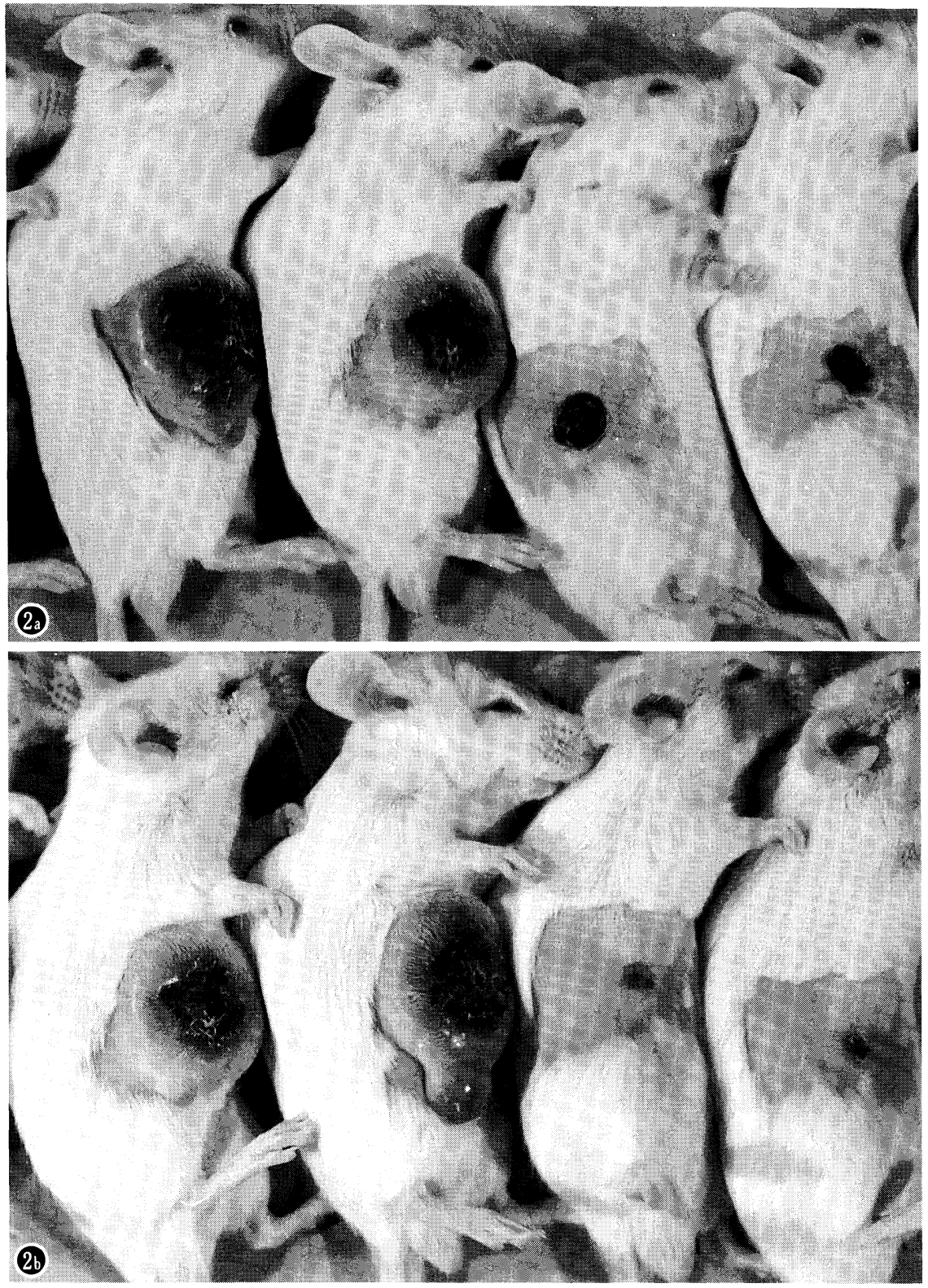

Fig. 2. rTNF-induced hemorrhagic necrosis and complete regression in Meth A-bearing $\mathrm{BALB} / \mathrm{c}$ mice.

rTNF ( $3 \times 10^{3}$ units/day) was administrated i.t. as shown Table 1. a) rTNFtreated mice ( 2 from the right) and untreated mice ( 2 from the left) on 10 days after tumor inoculation. b) rTNF-treated mice ( 2 from the right) and untreated mice ( 2 from the left) at day 15. 
TABLE 1. Treatment of Meth A-bearing mice with rTNF administrated i.t. and i.v.

\begin{tabular}{|c|c|c|c|c|c|}
\hline \multicolumn{2}{|c|}{$\mathrm{rTNF}^{*}$} & \multicolumn{2}{|c|}{ Hemorrhagic necrosis } & \multicolumn{2}{|c|}{ Complete regression $\dagger$} \\
\hline $\begin{array}{c}\text { Dose } \\
\text { (Units/mouse) }\end{array}$ & Route & (No. of mice/total) & $(\%)$ & (No. of mice/total) & $(\%)$ \\
\hline \multirow[t]{2}{*}{ Noneł } & i.t. & $0 / 10$ & (0) & $0 / 10$ & (0) \\
\hline & i.v. & $0 / 10$ & (0) & $0 / 10$ & (0) \\
\hline \multirow[t]{2}{*}{$1 \times 10^{3}$} & i.t. & $10 / 10$ & $(100)$ & $0 / 10$ & (0) \\
\hline & i.v. & $0 / 10$ & $(0)$ & $0 / 10$ & $(0)$ \\
\hline \multirow[t]{2}{*}{$3 \times 10^{3}$} & i.t. & $10 / 10$ & $(100)$ & $6 / 10$ & (60) \\
\hline & i.v. & $10 / 10$ & $(100)$ & $2 / 10$ & (20) \\
\hline \multirow[t]{2}{*}{$5 \times 10^{3}$} & i.t. & $10 / 10$ & (100) & $9 / 10$ & (90) \\
\hline & i.v. & $10 / 10$ & (100) & $3 / 10$ & (30) \\
\hline
\end{tabular}

${ }^{*} \mathrm{rTNF}$ was injected i.t. and i.v. once daily from 5 to 7 days after mice were inoculated with Meth A $\left(5 \times 10^{5}\right)$.

†Complete tumor regression was defined when tumor was not regrown for more than 2 months.

$\ddagger$ Phosphate-buffered saline containing $0.1 \%$ gelatin was used as untreated controls.

with 3 different doses of rTNF by several injection routes such as intratumorally (i.t.), intravenously (i.v.), subcutaneously (s.c.) and intraperitoneally (i.p.). Complete regression was observed in more than $60 \%$ of mice when 3,000 units $\mathrm{rTNF} /$ mouse/day and more were administrated i.t. (Table 1). Hemorrhagic necrosis was also caused by one third of that dose. However, in the case of i.v., both the regressive and the necrotic effects were less effective than those of i.t. (Table 1). Other administration routs tested such as s.c. and i.p. were essentially no effect on the both parameters. Indeed, when rTNF (5,000 units) was administrated i.v., serum levels of rTNF were rapidly disappeared. The half span was approximately $25 \mathrm{~min}$ and TNF was reduced to undetectable amount by $6 \mathrm{hr}$. In the case of i.p., s.c., and i.t., TNF in serum was detected a little or none at any time tested up to $6 \mathrm{hr}$. Furthermore, two courses of the 3-day-consecutive injection (days 5-7 and 14-16) were slightly more effective on the regression and necrosis than the single course (Figs. 1, 2, Table 1). Survival time was also prolonged by the two course administration of 3,000 units $\mathrm{rTNF} / \mathrm{mouse} /$ day (Fig. 1). Once i.t. injection of rTNF of the highest dose ( 5,000 units/mouse) at day 5 showed necrotic response and inhibition of an increase in the tumor weight up to the first week. However, after 1 week tumor was regrown and the weight was similar to that of the untreated control mice by day 25 .

Antitumor effect of rTNF on Sarcoma-180 in ddY mice was also studied. Similar treatment effect was seen when the mice were treated with the same protocol used for Meth A-bearing mice (Fig. 3). Sarcoma-180 was more sensitive to rTNF than Meth A, because less doses of rTNF were required to cause complete regression, to inhibit the tumor growth, and to prolong survival time (Fig. 3). 


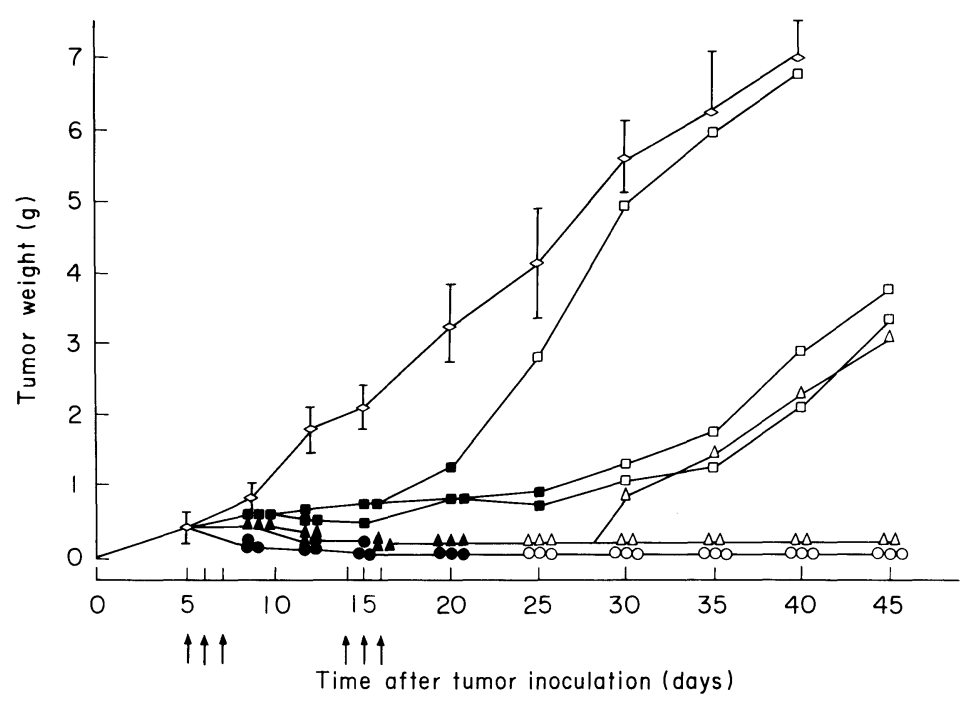

Fig. 3. Treatment with rTNF of ddY mice transplanted with Sarcoma-180. Sarcoma-180 $\left(10^{6}\right.$ cells $)$ was inoculated i.d. and $50 \mu \mathrm{l}$ of various concentrations of rTNF was injected i.t. at days indicated by allows. The doses of rTNF used were none $(\diamond), 10^{3}$ units $(\square, \boldsymbol{\square}), 3 \times 10^{3}$ units $(\triangle, \mathbf{\Delta})$, and $5 \times 10^{3}$ units $(\bigcirc$, •) per day. Closed symbols show hemorrhagic necrosis occurred.

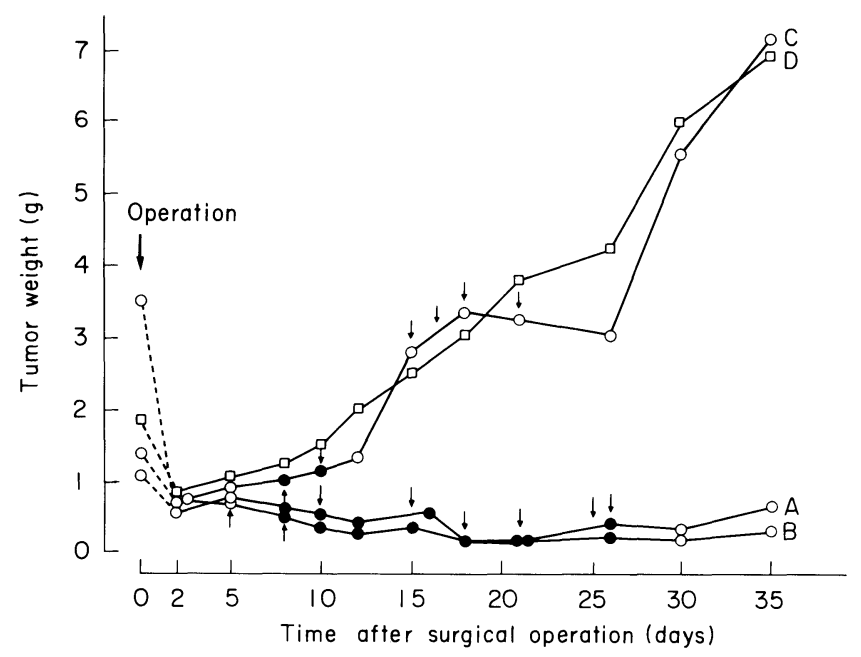

Fig. 4. rTNF-treatment of surgically operated-mice transplanted with Sarcoma180. Mouse $\mathrm{A}, \mathrm{B}$, and $\mathrm{C}(0)$ were treated with $\mathrm{rTNF}\left(5 \times 10^{3}\right.$ units/day/ mouse) indicated by the small allows in the figure. Mouse $\mathrm{D}\left(_{-}^{-}\right)$was a untreated control. Closed symbols show hemorrhagic necrosis occurred. "operation" means the reduction surgery was carried out and that day was defined as day 0 . The tumor weight before the "operation" is shown by a larger allow. 


\section{Treatment of Sarcoma-180-bearing mice after reduction surgery}

We have found that complete tumor regression in both Meth A- and Sarcoma180-bearing mice is induced. However, there was no curative effect by rTNF even with more multiple daily injections when the tumor weight was more than $1 \mathrm{~g}$ which was approximately 10 days and later after tumor inoculation. Thus, the effect of rTNF on the Sarcoma-180-bearing mice partially removed the tumor surgically was then studied. Mice with 1.2 to $3.5 \mathrm{~g}$ of the tumor were operated to reduce the tumor weight less than $0.5 \mathrm{~g}$. When Sarcoma-180 was regrown and became 0.3 to $0.8 \mathrm{~g}$ in 5 days after the operation, rTNF (5,000 units/mouse/day) was injected i.t. 4 times a week. Three out of 10 mice treated with rTNF were cured from the tumor. Severe necrotic effect was also observed in all mice tested. The results of one experiment were shown in Fig. 4. Most mice failed to cure like mouse $\mathrm{C}$ in Fig. 4 had relatively large tumor (approximately $1 \mathrm{~g}$ on day 5). Untreated mice (mouse D in Fig. 4) were died within 35 days after the operation developing the tumor regrowth.

\section{Rechallenge by tumor in cured mice}

Establishment of the specific immunity to a certain tumor in mice cured by rTNF was next studied. Four of the $6 \mathrm{BALB} / \mathrm{c}$ mice cured from Meth A were rejected the take of same tumor Meth A, but not the different RL $\uparrow 1$ (Table 2). The rest of 2 mice died as well as the control mice. In addition, the ddY mice cured from Sarcoma-180 were completely rejected the same tumor. However, Ehrlich ascitic tumor killed the cured ddY mice (Table 2). These results indicate that the specific immunity is induced in the mice treated with rTNF.

TABLE 2. Tumor take in cured mice rechallenged by same or different tumors

\begin{tabular}{|c|c|c|c|}
\hline \multirow{2}{*}{ Mouse } & \multirow{2}{*}{$\begin{array}{l}\text { Rechallenged } \\
\text { tumor }\end{array}$} & \multicolumn{2}{|c|}{ Tumor-free mice } \\
\hline & & number/tested & $(\%)$ \\
\hline \multicolumn{4}{|l|}{ Untreated } \\
\hline BALB/c & Meth A & $0 / 6$ & $(0)$ \\
\hline $\operatorname{dd} \mathrm{Y}$ & Sarcoma-180 & $0 / 6$ & $(0)$ \\
\hline Cured from Meth A & Meth A & $4 / 6$ & (67) \\
\hline $\mathrm{BALB} / \mathrm{c}$ & $\mathrm{RL}_{\circlearrowleft} 1$ & $0 / 6$ & $(0)$ \\
\hline \multicolumn{4}{|c|}{ Cured from Sarcoma-180 } \\
\hline \multirow[t]{2}{*}{ ddY } & Sarcoma-180 & $4 / 4$ & $(100)$ \\
\hline & Ehrlich & $0 / 4$ & $(0)$ \\
\hline
\end{tabular}

The mice cured by rTNF treatment were reinoculated i.d. The tumor take was examined 4 weeks later. 
TABLE 3. No effect of in vivo treatment of $r T N F$ on splenic NK activity and ADCC of peritoneal exuded cells in $B A L B / c$ mice*

\begin{tabular}{lccccc}
\hline \multirow{2}{*}{ Treatment } & \multicolumn{4}{c}{ Specific lysis (\%) } \\
\cline { 2 - 3 } \cline { 5 - 6 } & \multicolumn{2}{c}{ NK activity } & & \multicolumn{2}{c}{ ADCC } \\
\cline { 2 - 3 } \cline { 5 - 6 } & $24 \mathrm{hr}$ & $48 \mathrm{hr}$ & & $24 \mathrm{hr}$ & $48 \mathrm{hr}$ \\
\hline None $\dagger$ & $0.7 \pm 1.9$ & $-2.2 \pm 1.7$ & & $19.9 \pm 0.8$ & $17.6 \pm 1.3$ \\
$\mathrm{rTNF}$ & $0.8 \pm 2.2$ & $-0.9 \pm 3.4$ & & $17.9 \pm 1.8$ & $22.3 \pm 0.4$ \\
$\mathrm{IFN}-\alpha \mathrm{A} / \mathrm{D}$ & $17.4 \pm 1.2$ & $8.7 \pm 2.7$ & & $21.5 \pm 2.3$ & $41.8 \pm 3.3$ \\
\hline
\end{tabular}

${ }^{*} \mathrm{rTNF}\left(3 \times 10^{3}\right.$ units/mouse $)$ and IFN- $\alpha \mathrm{A} / \mathrm{D}\left(10^{5}\right.$ units/mouse $)$ were injected i.p. into mice.

Splenocytes for NK activity and peritoneal exuded cells for ADCC were isolated at time indicated. Effector-to-target cell ratio used for NK activity and ADCC was $100: 1$ and $5: 1$, respectively. Values are means \pm s.D. of triplicate samples.

$\nmid$ Phosphate-buffered saline containing $0.1 \%$ gelatin was used as a untreated control.

No effect on NK activity, ADCC and IFN induction in mice treated with rTNF in vivo

The effects of rTNF on in vivo immune parameters such as NK activity, ADCC, and IFN titer were examined. The augmentation of NK activity of splenocytes, induction of ADCC of peritoneal exuded cells in rTNF-treated normal mice were not observed at all, while IFN- $\alpha \mathrm{A} / \mathrm{D}$ used as positive control induced these activities (Table 3). Similar results were obtained in Meth Abearing mice (data not shown). Further, rTNF (3,000 units/mouse) was administrated, a significant increase in IFN activities in serum of both normal and Meth A-bearing mice was not detected at 1 to $96 \mathrm{hr}$.

\section{Discussion}

We have demonstrated that rTNF has a potent antitumor effect and induces hemorrhagic necrosis and complete tumor regression in both Meth A- and Sarcoma-180-bearing mice, when administrated i.t. with multiple injections at less than $0.8 \mathrm{~g}$ of the tumor weights. In agreement with Creasey et al. (1986), the method of rTNF administration is critical for the use in cancer and multiple injections are most effective for accomplishing complete tumor regression. They also reported that i.v. administration is more effective than i.p. in the tumor regression. However, the i.t. administration was much more effective than the other routes for causing both necrotic response and regression (Table 1). This observation supports previous findings that both gene-cloned and natural TNF elicits significant necrotic responses of Meth A-bearing BALB/c mice with single administration intralesionally or i.v. (Carswell et al. 1975; Haranaka et al. 1984 ; Pennica et al. 1984). Hayashi et al. (1986) reported that when rTNF was administrated i.v., rTNF markedly accumulates the tumor tissue and the half life 
is approximately $30 \mathrm{~min}$ in tumor-bearing mice. However, TNF was not detected in the serum by i.t. administration. These and our results indicate that rTNF by i.t. administration may retain longer time in tumor tissue than the other routes.

Carswell et al. (1975) reported that the maximal necrotic response induced by serum containing TNF was observed on day 7 at which the transplants were established well, and less effective on day 5 or 6 . While our experimental conditions were a little different, similar observations were obtained (Table 1). However, necrotic response induced by rTNF does not always lead to complete regression and it was depend on the dose used and the routes administrated (Table 1 and Fig. 1). Further, it is important to attain the stage of the complete regression that the tumor weight is between $0.3-0.8 \mathrm{~g}$ when treatment is started but not the days after tumor inoculation. Because the treatment of both primarily transplanted tumor and the tumor received reduction surgery was succeeded (Figs. 1, 4).

TNF shows in vitro cytotoxic activity to a wide variety of human and animal malignant cell including cell lines and fresh cells of cancer patients in primary culture (Carswell et al. 1975; Ha et al. 1985 ; Haranaka et al. 1985 ; Watanabe et al. 1985). However, rTNF at the concentrations of 1 to $1,000 \mathrm{units} / \mathrm{ml} \mathrm{did}$ not show any direct cytotoxicity to Meth A and Sarcoma-180 in primary culture (our unpublished results), indicating that the necrotic effect and the tumor regression are not direct action by rTNF. Several groups reported that TNF shows no toxicity to cultured Meth A (Carswell et al. 1975; Ruff and Gifford 1981; Sugarman et al. 1985; Yoshie et al. 1986) except 3 groups (Ha et al. 1985 ; Haranaka et al. 1985; Kull et al. 1985), although Meth A has TNF receptors (Kull et al. 1985; Yoshie et al. 1986). There is no correlation between the number of TNF receptors on the cell surface and expression of the cytotoxicity (Kull et al. 1985 ; Yoshie et al. 1986). TNF stimulates the release of coagulation factor by vascular endothelial cells and this believed to cause hemorrhagic necrosis in tumor tissue (Bevilacqua et al. 1986; Nawroth and Stern 1986). These observations and the present results indicate that TNF exerts on Meth A and Sarcoma-180 tumors an indirect action including the stimulation of releasing a factor(s) which destroy the tumor tissue in a short term. In addition, there are another data supporting the indirect action that TNF induces the activation and differentiation of monocytes/macrophages and neutrophils in vitro (Gamble et al. 1985 ; Shalaby et al. 1985; Munker et al. 1986 ; Philip and Epstein 1986; Takeda et al. 1986; Urban et al. 1986). The activated myelocytic cells may attack the tumor locally, to cause the necrosis earlier and then regress the tumor later. However, the most macrophage functions such as tumor killing and production of cytokines require a certain time (Philip and Epstein 1986; Urban et al. 1986). ADCC, one of the activated macrophage functions, was not induced (Table 3 ). Thus, it is likely that induction of differentiation and/or activation of macrophages by TNF involve the response occurred in the later events such as tumor regression and 
establishment of the tumor-specific immunity rather than events occurred earlier. Further, the present observations that there is neither induction of IFN nor NK activity, also support that the activation of immunoregulatory cells by TNF itself is not involved in the primary tumor necrosis. Although TNF itself has no effect on the induction of IFN and NK activity, mice cured from tumor by treatment with TNF acquire tumor specific immunity. This might be due to the activation of host immunoregulatory cells such as memory killer cells by tumor antigen derived from disseminated tumor tissue.

Multipotential activities of TNF have been shown, which are not only induction of tumor regression but also activation of hematopoietic cells such as macrophages, neutrophils, eosinophils, and natural cytotoxic cells (Gamble et al. 1985 ; Shalaby et al. 1985; Ortaldo et al. 1986 ; Philip and Epstein 1986; Silberstein and David 1986; Urban et al. 1986). In addition, TNF is identical to cachectin which is released by macrophages stimulated with endotoxin and an inhibitor of gene expression and activity of lipoprotein lipase (Beutler et al. 1985 ; Beutler and Cerami 1986). Cachexia-induced mice by endotoxin loose the weight (Beutler and Cerami 1986). During our study the mice treated with rTNF at doses induced into complete regression also decreased 5 to $25 \%$ of the body weight (unpublished observation). To reveal an activity of multipotential TNF functions, it is important that choose an optimal dose and timing of the tumor treatment.

\section{Acknowledgments}

We thank Emi Shibuya for her excellent technical assistance and the Asahi Chemical Industry, Co. Ltd. for providing rTNF and antibodies to TNF.

\section{References}

1) Aso, H., Suzuki, F., Yamaguchi, T., Hayashi, Y., Ebina, T. \& Ishida, N. (1985) Induction of interferon and activation of NK cells and macrophages in mice by oral administration of Ge-132, an organic germanium compound. Microbiol. Immunol., 29, 65-74.

2) Beutler, B. \& Cerami, A. (1986) Cachectin and tumor necrosis factor as two side of the same biological coin. Nature, 320, 584-588.

3) Beutler, B., Greenwald, D., Hulmes, J.D., Chang, M., Pan, Y-C.E., Mathison, J., Ulevitch, R. \& Cerami, A. (1985) Identity of tumor necrosis factor and the macrophage-secreted factor cachectin. Nature, 316, 552-554.

4) Bevilacqua, M.P., Pober, H.M., Majeau, G.R., Fiers, W., Cotran, R.S. \& Gimbrone, M.A., Jr. (1986) Recombinant tumor necrosis factor induces procoagulant activity in cultured human vascular endothelium: Characterization and comparison with the actions of interleukin 1. Proc. Natl. Acad. Sci. USA, 83, 4533-4537.

5) Carswell, E.A., Old, L.J., Kassel, R.L., Green, S., Fiore, N. \& Williamson, B. (1975) An endotoxin-induced serum factor that causes necrosis of tumors. Proc. Natl. Acad. Sci. USA, 72, 3666-3670.

6) Creasey, A.A., Reynolds, M.T. \& Laird, W.I. (1986) Cures and partial regression of mouse and human tumors by recombinant human tumor necrosis factor. Cancer Res., 46, $5687-5690$. 
7) Fisch, H. \& Gifford, G.E. (1983) In vitro production of rabbit macrophage tumor cell cytotoxin. Int. J. Cancer, 32, 105-112.

8) Gamble, J.R., Harlan, J.M., Klebanoff, S.J. \& Vadas, M.A. (1985) Stimulation of the adherence of neutrophils to umbilical vein endothelium by human recombinant tumor necrosis factor. Proc. Natl. Acad. Sci. USA, 82, 8667-8671.

9) Ha, D.K.K., Leung, S.W., Fung, K.P., Choy, Y.H. \& Lee, C.Y. (1985) Production of tumor necrosis factor in Listeria monocytogenes-infected animals. Int. J. Immunopharmacol., 7, 1-6.

10) Haranaka, K., Satomi, N. \& Sakurai, A. (1984) Antitumor activity of murine tumor necrosis factor (TNF) against transplanted human tumors in nude mice. Int. $J$. Cancer, 34, 263-267.

11) Haranaka, K., Satomi, N., Sakurai, A. \& Nariuchi, H. (1985) Purification and partial amino acid sequence of rabbit tumor necrosis factor. Int. J. Cancer, 36, 395-400.

12) Hayashi, H., Kiyota, T., Sakamoto, H. \& Seto, M. (1986) An enzyme-linked immunosorbent assay for recombinant human tumor necrosis factor using monoclonal antibody. In : Recent Advance in Chemotherapy, edited by J. Ishigami, Univ. Tokyo Press, Tokyo, pp. 820-821.

13) Hemmi, H., Nakamura, T., Tamura, K., Shimizu, Y., Kato, S., Miki, T., Takahashi, N., Muramatsu, M., Numao, N. \& Sugamura, K. (1987) Lymphotoxin: Induction of terminal differentiation of the human myeloid leukemia cell lines, HL-60 and THP-1. J. Immunol., 138, 664-666.

14) Kelker, H.C., Oppenheim, J.D., Stone-wolff, D., Henriksen-deStefano, D., Aggarwal, B. B., Stevenson, H.C. \& Vilcek, J. (1985) Characterization of human tumor necrosis factor produced by peripheral blood monocytes and its separation from lymphotoxin. Int. J. Cancer, 36, 69-73.

15) Kull, F.C., Jacobs, S. \& Cuatrecasas, P. (1985) Cellular receptor for ${ }^{125}$ I-labeled tumor necrosis factor: Specific binding, affinity labeling, and relationship to sensitivity. Proc. Natl. Acad. Sci. USA, 82, 5756-5760.

16) Marmenout, A., Fransen, L., Tavernier, J., Van Der Heyden, J., Tizard, R., Kawashima, E., Shaw, A., Johnson, M., Semon, D., Muller, R., Ruysschaert, M., Van Viet, A. \& Fiers, W. (1985) Molecular cloning and expression of human necrosis factor and comparison with mouse tumor necrosis factor. Eur. J. Biochem., 152, 515-522.

17) Matthews, N. (1981) Production of an antitumor cytotoxin by human monocytes. Immunology, 44, 135-142.

18) Matthews, N. (1983) Effect on human monocyte killing of tumor cells of antibody raised against an extracellular monocyte cytotoxin. Immunology, 48, 321-327.

19) Munker, R., Gasson, J., Ogawa, M. \& Koeffler, H.P. (1986) Recombinant human TNF induces production of granulocyte-monocyte colony stimulating factor. Nature, 323, 79-81.

20) Nakamura, T., Hemmi, H., Aso, H. \& Ishida, N. (1986) Variants of a human monocytic leukemia cell line (THP-1): Induction of differentiation by retinoic acid, interferon- $\gamma$, and T-lymphocyte-derived differentiation-inducing activity. J. Natl. Cancer Inst., 77, 21-27.

21) Nawroth, P.P. \& Stern, D.M. (1986) Modulation of endothelial cell hemostatic properties by tumor necrosis factor. J. Exp. Med., 163, 740-745.

22) Ortaldo, J.R., Mason, L.H., Mathieson, B.J., Liang, S-M., Flick, D.A. \& Herberman, R.B. (1986) Mediation of mouse natural cytotoxic activity of tumor necrosis factor. Nature, 321, 700-702.

23) Pennica, D., Nedwin, G.E., Hayflick, J.S., Seeburg, P.H., Derynck, R., Palladino, M.A., Kohr, W.J., Aggarwall, B.B. \& Goeddel, D.V. (1984) Human tumor necrosis factor: Precusor structure, expression and homology to lymphotoxin. Nature, 312, 724-729.

24) Philip, R. \& Epstein, L.B. (1986) Tumor necrosis factor as immunomodulator and mediator of monocyte cytotoxicity induced by itself, $\gamma$-interferon and interleukin-1. 
Nature, 323, 86-89.

25) Ruff, M.R. \& Gifford, G.E. (1981) Tumor necrosis factor. In : Lymphokines, Vol. 2, edited by E. Pick, Academic Press, New York, pp. 235-273.

26) Shalaby, M.R., Aggarwal, B.B., Rinderknecht, E., Svedersky, L.P., Finkle, B.S. \& Palladino, M.A., Jr. (1985) Activation of human polymorphonuclear neutrophil functions by interferon- $\gamma$ and tumor necrosis factors. J. Immunol., 135, 2069-2073.

27) Shirai, T., Yamaguchi, H., Ito, H., Todd, D.W. \& Wallace, R.B. (1985) Cloning and expression in Escherichia coli of the gene for human tumor necrosis factor. Nature, 313, 803-806.

28) Silberstein, D.S. \& David, J.R. (1986) Tumor necrosis factor enhances eosinophil toxicity to Schistosoma mansoni larvae. Proc. Natl. Acad. Sci. USA, 83, 1055-1059.

29) Sugarman, B.J., Aggarwal, B.B., Hass, P.E., Figari, I.S., Palladino, M.A., Jr. \& Shepard, H.M. (1985) Recombinant human tumor necrosis factor- $\alpha$ : Effects on proliferation of normal and transformed cell in vitro. Science, 230, 943-945.

30) Takeda, K., Iwamoto, S., Sugimoto, H., Takuma, T., Kawatani, N., Noda, M., Masaki, A., Morise, H., Arimura, H. \& Konno, K. (1986) Identity of differentiation inducing factor and tumor necrosis factor. Nature, 323, 338-340.

31) Urban, J.L., Shepard, H.M., Rothestein, J.L., Sugarman, B.J. \& Schreiber, H. (1986) Tumor necrosis factor: A potent effector molecule for tumor cell killing by activated macrophages. Proc. Natl. Acad. Sci. USA, 83, 5233-5237.

32) Watanabe, N., Niitsu, Y., Neda, H., Sone, H., Yamauchi, N., Umetsu, T. \& Urushizaki, I. (1985) Antitumor effect of tumor necrosis factor against various primarily cultured human cancer cells. Jpn. J. Cancer Res. (GANN), 76, 1115-1119.

33) Yamazaki, S., Onishi, E., Enami, K., Natori, K., Kohase, M., Sakamoto, H., Tanouchi, M. \& Hayashi, H. (1986) Proposal of standardized methods and reference for assaying recombinant human tumor necrosis factor. Jpn. J. Med. Sci. Biol., 39, 105-118.

34) Yoshie, O., Tada, K. \& Ishida, N. (1986) Binding and crosslinking of ${ }^{125}$ I-labeled recombinant human tumor necrosis factor to cell surface receptors. J. Biochem., 100, 531-541. 